\title{
Publisher Correction: UBE4B, a microRNA-9 target gene, promotes autophagy-mediated Tau degradation
}

Manivannan Subramanian, Seung Jae Hyeon, Tanuza Das, Yoon Seok Suh, Yun Kyung Kim (D), Jeong-Soo Lee (D), Eun Joo Song (1), Hoon Ryu \& Kweon Yu (D)

Correction to: Nature Communications https://doi.org/10.1038/s41467-021-23597-9, published online 2 June 2021.

In the original version of this Article, Figs. $4 \mathrm{a}, \mathrm{b}, \mathrm{d}$, and e were missing the black circles indicating which plasmids were used in the experiments. This error has now been fixed, and the PDF and HTML versions of the Article contain corrected Fig. 4.

Published online: 07 July 2021

\footnotetext{
(c) Open Access This article is licensed under a Creative Commons Attribution 4.0 International License, which permits use, sharing, adaptation, distribution and reproduction in any medium or format, as long as you give appropriate credit to the original author(s) and the source, provide a link to the Creative Commons license, and indicate if changes were made. The images or other third party material in this article are included in the article's Creative Commons license, unless indicated otherwise in a credit line to the material. If material is not included in the article's Creative Commons license and your intended use is not permitted by statutory regulation or exceeds the permitted use, you will need to obtain permission directly from the copyright holder. To view a copy of this license, visit http://creativecommons.org/licenses/by/4.0/.
}

(C) The Author(s) 2021 